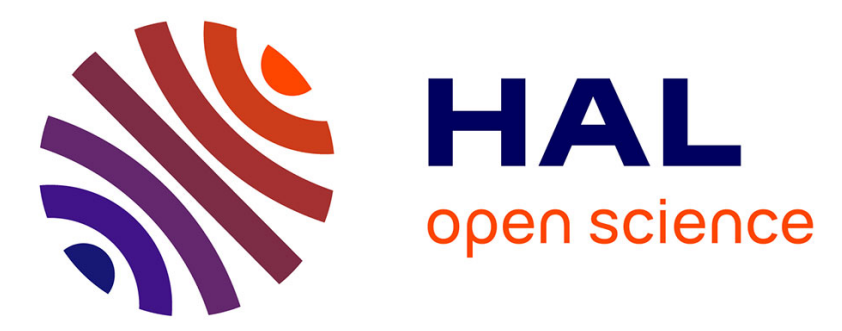

\title{
The amino acid composition of rainbow trout (Salmo gairdneri) seminal fluid and blood plasma: A comparison with carp (Cyprinus carpio)
}

Roland Billard, Y. Menezo

\section{- To cite this version:}

Roland Billard, Y. Menezo. The amino acid composition of rainbow trout (Salmo gairdneri) seminal fluid and blood plasma: A comparison with carp (Cyprinus carpio). Aquaculture, 1984, 41 (3), pp.255-258. 10.1016/0044-8486(84)90288-6 . hal-01600564

\section{HAL Id: hal-01600564 \\ https://hal.science/hal-01600564}

Submitted on 2 Jun 2020

HAL is a multi-disciplinary open access archive for the deposit and dissemination of scientific research documents, whether they are published or not. The documents may come from teaching and research institutions in France or abroad, or from public or private research centers.
L'archive ouverte pluridisciplinaire HAL, est destinée au dépôt et à la diffusion de documents scientifiques de niveau recherche, publiés ou non, émanant des établissements d'enseignement et de recherche français ou étrangers, des laboratoires publics ou privés.

\section{다(1)(2)}

Distributed under a Creative Commons Attribution - ShareAlikel 4.0 International 


\title{
THE AMINO ACID COMPOSITION OF RAINBOW TROUT (SALMO GAIRDNERI) SEMINAL FLUID AND BLOOD PLASMA: A COMPARISON WTTH CARP (CYPRINUS CARPIO)
}

\author{
R. BILLARD ${ }^{1}$ and Y. MENEZO'
}

' Station de Physiologie Animale et Laboratoire de Physiologie des Poissons - INRA, 78350 Jouy-en-Josas et Campus de Beaulieu, 35042 Rennes (France)

${ }^{2}$ Laboratoire de Biologie Générale - INSA INRA, 20 avenue A. Einstein, 69621 Villeurbanne Cédex (France)

(Accepted 26 May 1984)

\section{ABSTRACT}

Billard, R. and Menezo, Y., 1984. The amino acid composition of rainbow trout (Salmo gairdneri) seminal fluid and blood plasma: a comparison with carp (Cyprinus carpio). Aquaculture, $41: 255-258$.

Free amino acids in blood plasma and seminal fluid of 10 rainbow trout males were assayed in mid-spermiation using the same techniques. Many amino acids in the blood plasma were not found in the seminal fluid and there was no relationship between the level of any one of the amino acids in the blood and that found in the seminal fluid. Total amino acids in the seminal fluid were one-tenth of those in the blood in trout and four times more in the carp.

\section{INTRODUCTION}

The composition of seminal fluid and of other biological fluids can be used as a reference for making media to be used as diluents or for gamete storage. The amino acid composition of these fluids has been determined in mammals (Menezo, 1975) and their mineral (Billard and Jalabert, 1971) and protein (Angelov et al., 1982) compositions in fish. The present study reports the amino acid compositions of blood plasma and seminal fluid in rainbow trout (Salmo gairdneri) and compares them with data for carp (Cyprinus carpio) reported in the literature.

\section{MATERIAL AND METHODS}

Male trout from the fish farm of Lubin with a weight between 0.8 and $1.5 \mathrm{~kg}$ were sampled in mid-spermiation in December when the water temperature was below $10^{\circ} \mathrm{C}$. Using heparinized $10-\mathrm{ml}$ syringes (sodium salt of heparin), blood was taken from the tail vasculature of each of the 10 males and sperm was collected by a catheter introduced half-way into the free part 
of the spermiduct. The blood and milt were centrifuged at $3600 \times g$ for 20 $\min$ and the supernatant was stored at $-20^{\circ} \mathrm{C}$ until assay. Details on carp sperm collection have been given in Menezo et al. (1983).

The protein precipitation techniques have been described by Meneżo (1975) and Menezo et al. (1983). Deproteinization was carried out by adding sulfosalicylic acid ( $30 \mathrm{mg} / \mathrm{ml}$ seminal fluid or plasma). Two inner staining references were added at the same time ( $\alpha$-amino- $\beta$-guanidinopropionic acid and norvaline). The precipitate was discarded by centrifugation at $3500 \times \mathrm{g}$ for $3 \mathrm{~min}$. Quantitative analysis of asparagine and glutamine was effected by liquid chromatography using lithium buffer.

\section{RESULTS AND DISCUSSION}

Table I gives amino acid composition values (in $\mathrm{nM} / \mathrm{ml}$ ) of rainbow trout as compared with those in the literature for carp. In trout, free amino acids levels were much lower in the seminal fluid than in the blood plasma. There was no relationship between the amounts found in the two compartments; for example, alanine levels were among the highest in the blood plasma but were relatively low in the seminal fluid. On the contrary, some amino acids (phosphoethanolamine and phosphoserine) found only in low quantities in the blood appeared in relatively high amounts in the seminal fluid. Moreover, not all the amino acids present in the blood were detectable in the seminal fluid. The values for urea were comparable in the two compartments. The values found in plasma were elose to, although slightly lower than, those reported by Mehrle et al. (1971) for blood serum in immature trout. A comparison of our data on seminal fluid with those of BonafonteZaragozano (1978) shows similarities for most of the amino acids. However, that author did not assay basic amino acids such as arginine, histidine and lysine, and thus there was no way of checking the $\beta$-alanine identified in that study with that which we found in small traces in our assays.

A comparison of data on rainbow trout with those of carp shows very wide differences, particularly as regards the amino acid ratios between the seminal fluid and blood plasma ( 0.11 for rainbow trout, 3.77 for carp). This ratio reached 5.55 in carp if the amino acids were considered after peptide hydrolysis. The regulation of amino acid composition in the seminal fluid seems to be more heterogeneous in fish than in mammals. The amino acid concentration in trout seminal fluid was low compared to that of carp which shows a high level of small peptides (Menezo et al., 1983). The mechanisms and sites of the formation of seminal fluid may be different in the two species; the spermiduct in trout is more highly developed than in carp and this could lead to different processes of secretion and reabsorption. Because small peptides are present in carp seminal fluid, neosynthesis may be more intense and intratesticular. The differences in composition could also be related to sperm physiology which differs greatly in carp and trout; motility lasts longer in carp than in trout (Billard, unpublished data, 1980), 
TABLE I

Amino acid composition of blood plasma and seminal fluid in trout compared with carp

\begin{tabular}{|c|c|c|c|c|}
\hline \multirow[t]{2}{*}{ Amino acid } & \multicolumn{2}{|l|}{ Trout } & \multicolumn{2}{|l|}{ Carp } \\
\hline & $\begin{array}{l}\text { Blood } \\
\text { plasma }^{\mathbf{a}}\end{array}$ & $\begin{array}{l}\text { Seminal } \\
\text { fluid }\end{array}$ & $\begin{array}{l}\text { Blood } \\
\text { plasma }^{b}\end{array}$ & $\begin{array}{l}\text { Seminal } \\
\text { fluid }^{c}\end{array}$ \\
\hline Taurine & $630 \pm 115$ & $82 \pm 46$ & 363 & 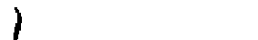 \\
\hline $\begin{array}{l}\text { Phosphoethanolamine } \\
+ \text { Phosphoserine }\end{array}$ & $+d$ & 35 & & 3127 \\
\hline Asp. + Asp. $\mathrm{NH}_{2}$ & $216+40$ & $20 \pm 7$ & & 948 \\
\hline Threonine & $307 \pm 110$ & $15 \pm 5$ & 342 & $623(1788)$ \\
\hline Serine & $137 \pm 29$ & $10 \pm 3$ & 59 & $320(610)$ \\
\hline Glu. + Glu. $\mathrm{NH}_{2}$ & $480 \pm 100$ & $23 \pm 10$ & & $7110(14369)$ \\
\hline Glycine & $172 \pm 57$ & $14 \pm 8$ & 125 & $2118(26.23)$ \\
\hline Alanine & $653 \pm 93$ & $19 \pm 9$ & & $822(1929)$ \\
\hline Proline & + & + & 4266 & $5413(7335)$ \\
\hline Citrulline & $20 \pm$ & + & & + \\
\hline Cystine & + & + & & 27 \\
\hline Valine & $556 \pm 110$ & $13 \pm 4$ & 460 & $336(458)$ \\
\hline Methionine & $158 \pm 36$ & $17 \pm 8$ & 56 & $17(\mathbf{1 4 2 9 )}$ \\
\hline Isoleucine & $237 \pm 41$ & + & 195 & $173(251)$ \\
\hline Leucine & $415 \pm 93$ & + & 346 & $408(582)$ \\
\hline Tyrosine & $151 \pm 18$ & + & 41 & $355(515)$ \\
\hline Phenylalanine & $161 \pm 15$ & $\dot{+}$ & 10 & $195(212)$ \\
\hline Aminobutyric acids. & 99 & + & & $304(307)$ \\
\hline Ornithine & $85 \pm 11$ & $10 \pm 5$ & & $21(75)$ \\
\hline Lysine & $363 \pm 85$ & $23 \pm 15$ & 299 & $93(391)$ \\
\hline Histidine & $95 \pm 18$ & $9 \pm 3$ & 141 & $276(309)$ \\
\hline Tryptophan & + & + & & 23 \\
\hline Arginine & $79 \pm 32$ & $14 \pm 9$ & 23 & $13(118)$ \\
\hline Urea & $152 \pm 31$ & $101 \pm 26$ & & 2234 \\
\hline$\beta$-Alanine & + & + & & 90 \\
\hline Total & 5166 & 589 & 6613 & $24937(36696)$ \\
\hline
\end{tabular}

$\mathrm{a}_{n}=10$, values in $\mathrm{nM} / \mathrm{ml} \neq \mathrm{S} . \mathrm{D}$.

b From Plakas et, al., 1980.

cFrom Menezo et al, 1983.

$\mathbf{d}_{+}$detectable but not assayed.

In parentheses: values after peptide hydrolysis.

and amino acids such as proline (abundant in carp but present only in traces in trout) might form an energetic substrate. Fish spermatozoa are usually immotile in the seminal fluid; the factor inhibiting motility is potassium in trout (Schlenck and Kahmann, 1937; Billard, 1975) and osmotic pressure in carp (Morisawa et al., 1983). In the carp, osmotic pressure due to seminal fluid minerals (Plouidy and Billard, 1982), is not sufficient to inhibit motility, and at least the physical contribution of amino acids, peptides and proteins is needed. 
Another difference between carp and trout is the sperm quality which declines rapidly in trout during spermiation but remains at a good level of fertilizing ability throughout the year in carp. The wide variation observed in the amount and proportions of amino acids and peptides in the seminal fluid compared with the blood plasma might be related to the difference in sperm preservation and metabolism found in the two fish species.

\section{REFERENCES}

Angelov, A.I., Al-Khanak, H.M., Vassilevski, G.V. and Ivanova, M.G., 1982. Comparative electrophoretic investigations of the proteins from the seminal plasma of rainbow trout (Salmo gairdneri). C.R. Acad. BuIg. Sci., 35: 1295-1297.

Billard, R., 1975. L insémination artificielle de la truite Salmo gairdneri Richardson. IV. Effets des ions $\mathrm{K}^{+}$et $\mathrm{Na}^{+}$sur la conservation du pouvoir fécondant des gamètes. Bull. Fr. Piscic., 256: 88-100.

Billard, $R$ : and Jalabert, B., 1974. L'insémination artificielle de la truite Salmo gairdneri Richardson. Ir. Comparaison des effets de différents dilueurs sur la conservation de la fertilité đes gamètes avant et après insémination. Ann. Biol. Anim. Biochim. Biophyss., 14: $601-610$.

Bonafonte-Zaragozano, J.I., 1978. Determinacion e interrelaciones de los aminoacidos libres (acidos y neutros), presentes en el plasma seminal de trucha arco-iris (Salmo gairdneri). An. Fac. Vet., Zaragoza; 11/12: 193-209.

Mehrle, P.M., Stalling, D.L. and Bloomfield, R.A., 1971. Serum amino acids in rainbow trout (Salmo gairdneri) as affected by DDT and dieldrin. Comp. Biochem. Physiol., 38B: $373-377$.

Menezo, Y., 1975. Amino constituents of tubal and uterine fluids of the estrous ewe: comparison with blood serum and ram seminal fluid. In: E.S.E. Hafez and C.G. Thibault (Editors), The Biology of Spermatozoa. S. Karger, Basle, pp. 174-181.

Menezo, Y., Plouidy, M.G. and Billard, R., 1983. Sur la composition en acides aminnés libres et peptidiques du liquide séminal de carpe (Cyprinus carpio). C.R. Acad. Sci. Paris, série $t, 296: 67-70$.

Morisawa, M., Suzuki, K., Shimizu, H., Morisawa, S. and Yasuda, K., 1983. Effects of osmolality and potassium on motility of spermatozoa from freshwater cyprinid fishes. J. Exp. Biol., 107: 95-103.

Plakas, S.M., Katayam, T., Tanaka, Y. and Deshimaru, O., 1980. Changes in the levels of cireulating plasma free amino acids of carp (Cyprinus carpio) after feeding a protein and an amino acid diet of similar composition. Aquaculture, 21:307-322.

Plouidy, M.G. and Billard, R., 1982. The chemical composition of the companion fluids of gametes in the common carp (Cyprinus carpio). In: C,J.J. Richter and H.J.Th. Goos (Compilers), Reproductive Physiology of Fish. PUDOC, Wageningen, p. 134 .

Schlenk, W., Jr. and Kahlmann, H., 1937. Die chemische Zusammensetzung der Spermaliquors und ihre physiologische Bedeutung. Biochem. Z., 295: 283-301. 